\title{
Yield Enhancement and Better Micronutrients Uptake in Tomato Fruit through Potassium Humate Combined with Micronutrients Mixture
}

\author{
Ashfaq Ahmad Rahi ${ }^{1}$, Muhammad Akbar Anjum ${ }^{2, *}$, Javed Iqbal Mirza ${ }^{3}$, Saleha Ahmad Ali ${ }^{4}$, \\ Theodore Danso Marfo ${ }^{5}\left(\mathbb{D}\right.$, Shah Fahad ${ }^{6}$, Subhan Danish ${ }^{7}$ id and Rahul Datta ${ }^{8, *(D)}$
}

Citation: Rahi, A.A.; Anjum, M.A.; Iqbal Mirza, J.; Ahmad Ali, S.; Marfo, T.D.; Fahad, S.; Danish, S.; Datta, R. Yield Enhancement and Better Micronutrients Uptake in Tomato Fruit through Potassium Humate Combined with Micronutrients Mixture. Agriculture 2021, 11, 357. https://doi.org/10.3390/ agriculture 11040357

Academic Editors

Vasileios Antoniadis and Urs Feller

Received: 6 February 2021

Accepted: 2 April 2021

Published: 16 April 2021

Publisher's Note: MDPI stays neutral with regard to jurisdictional claims in published maps and institutional affiliations.

Copyright: (C) 2021 by the authors Licensee MDPI, Basel, Switzerland. This article is an open access article distributed under the terms and conditions of the Creative Commons Attribution (CC BY) license (https:// creativecommons.org/licenses/by/ $4.0 /)$
Pesticide Quality Control Laboratory, Multan 60000, Punjab, Pakistan; rahisenior2005@gmail.com

2 Department of Horticulture, Bahauddin Zakariya University, Multan 60800, Punjab, Pakistan

Botany Department, Minhaj University, Lahore 54000, Punjab, Pakistan; jimirza@yahoo.com

4 Department of Botany, University of Lahore, Lahore 54590, Punjab, Pakistan; salehaahmad220@gmail.com

5 Department of Environmental Management Technology, Cape Coast Technical University, P.O. Box DL 50, Cape Coast 00233, Ghana; theodore.marfo@cctu.edu.gh

6 Department of Agronomy, The University of Haripur, Haripur 22620, Pakistan; shah_fahad80@yahoo.com

7 Department of Soil Science, Bahauddin Zakariya University, Multan 60800, Punjab, Pakistan; sd96850@gmail.com

8 Department of Geology and Pedology, Faculty of Forestry and Wood Technology, Mendel University in Brno, 61300 Brno, Czech Republic

* Correspondence: akbaranjum@bzu.edu.pk (M.A.A.); Rahul.datta@mendelu.cz (R.D.); Tel.: +420-773990283 (R.D.)

Abstract: The deficiency of micronutrients and low organic matter (OM) status of soils are major hurdles in the optimum crop yield achievements. Humic substances can play an imperative role in the micronutrient bioavailability and improved crop yield by ameliorating the physicochemical soil properties. consumed as fresh food and in processed form. However, its susceptibility towards micronutrient deficiency causes a significant reduction in yield. That is why a current study was done to examine the influence of different potassium humate $(\mathrm{KH})$ levels, i.e., $0,5,10$, and $15 \mathrm{~kg} \mathrm{ha}^{-1}$ with micronutrients mixture $(\mathrm{MC})$, i.e., $0,50\left(\mathrm{Zn}=2.50, \mathrm{~B}=0.75, \mathrm{Fe}=2.50 \mathrm{~kg} \mathrm{ha}^{-1}\right), 75(\mathrm{Zn}=3.75$, $\left.\mathrm{B}=1.125, \mathrm{Fe}=3.75 \mathrm{~kg} \mathrm{ha}^{-1}\right)$ and $100 \%\left(\mathrm{Zn}=5.0, \mathrm{~B}=1.5, \mathrm{Fe}=5.0 \mathrm{~kg} \mathrm{ha}^{-1}\right)$ on the yield, biomass, harvesting index and uptake of the micronutrients in tomato. The results showed that increasing the level of K-humate significantly improved the yield (7.4 and 7.17\%), total biomass (6.38 and $6.59 \%)$, and harvesting the index (0.46 and $0.76 \%)$ of tomato. It also enhanced Fe uptake but did not affect B and $\mathrm{Zn}$ concentrations in the tomato fruit at $100 \% \mathrm{MC}+15 \mathrm{~kg} \mathrm{ha}^{-1} \mathrm{KH}$ over control in the autumn and spring seasons. In conclusion, both levels of K-humate 10 and $15 \mathrm{~kg} \mathrm{ha}^{-1}$ and MC 75 and $100 \%$ effectively enhance the yield, biomass, harvesting the index, and micronutrients (B, $\mathrm{Zn}$, and Fe) uptake in tomatoes.

Keywords: boron; iron; organic amendment; tomato; yield; zinc

\section{Introduction}

The loss of upper fertile soil due to intensive cropping, least micronutrients (MC) addition, heavy metals toxicity, low and no addition of organic matter (OM) is provoking problem. High temperature and less rainfall are the major causes of low OM and less microbial proliferation in the soil. In addition to the above, inorganic fertilizers and less or no organic amendments usage are also allied factors responsible for decreasing organic residues in the soil [1]. Furthermore, deficiency of micronutrients is also becoming a big hurdle to achieve the optimum yield. These micronutrients are essential as most of the enzymatic reactions are controlled by these micronutrients. Their deficiency in plants resulted in a significant reduction of yield attributes [2]. 
The soils of Pakistan are primarily alkaline, and excessive phosphatic fertilizers can cause an increased level of phosphorous concentration in the soils. Such an increase disturbs zinc's solubility and mobility $(\mathrm{Zn})$ in the soil and makes the soil $\mathrm{Zn}$-deficient [3-5]. In different micronutrients, Zinc (Zn) is an important one. It plays an imperative role in growth. Scientists have also documented that $\mathrm{Zn}$ is also involved in cell differentiation [6]. Balanced $\mathrm{Zn}$ in the plants strengthens their immune system and provides a greater survival level to the plants [7].

Similarly, Boron (B) is also essential for plants. Boron deficiency usually results in low transpiration, shortening of internodes, and death of plant growing point [8-11]. Furthermore, Iron (Fe) plays an imperative role in chlorophyll synthesis, cell respiration, carbohydrate manufacturing, sulphate reduction, and $\mathrm{N}$ assimilation $[12,13]$. However, most scientists suggest using organic amendments that are environmentally friendly to optimize the micronutrients in the crops. Among variable organic amendments, humic acids (HA) are widely found in manure, compost, peat, and sewage. Mainly HA products are manufactured from peat and lignite [14].

Humic acids, which are oxidized forms of lignite, usually contain approximately $30-60 \%$ humic acid that makes soils more productive. These humic compounds also enhance seed germination when applied as a soil amendment at the time of sowing. The use of humic acid has also been documented as an organic fertilizer, because its application efficaciously minimizes the inorganic fertilizers' application rates. Also, soil physical properties, i.e., soil drainage, aggregation stability, and aeration, become modified when humic acid is applied as a soil conditioner. Modification in humic compounds' physical and chemical attributes facilitates better micronutrient availability [12,15].

Tomato (Lycopersicon esculentum Mill.) ranks 3rd in production all over the world. Due to the high content of minerals, vitamins, and anti-cancerous attributes, tomato is widely consumed, either in the processed or fresh-fruit form [16]. At the global level, tomato is cultivated at 4.5 million ha, with a yield of 124 million tons. In Pakistan, L. esculentum per vegetable area is very low compared to other countries because of the deficiency of organic contents and micronutrients in the soils [2]. The area under L. esculentum cultivation is $57,000.21$ hectares, providing $577,000.80$ tons yield annually with an average of 10.09 tons ha $^{-1}$ yield in Pakistan [17].

Keeping in mind the importance of MC ( $\mathrm{Zn}, \mathrm{Fe}, \mathrm{B})$ and low level of soil organic carbon in Pakistan soils, the current experiment was conducted on tomatoes. The study's main objective was to assess the adequate level of micronutrient mixture in the presence and absence of potassium humate under variable growing seasons to improve the tomato yield, micronutrient concentration, and biomass. It is hypothesized that potassium humate $(\mathrm{KH})$ with foliar MC can significantly increase the micronutrient concentration, biomass, and yield of tomatoes under variation of growing seasons (autumn and spring).

\section{Material and Methodology}

\subsection{Research Area}

A field experiment was conducted in the vegetable research area of the Department of Horticulture, Bahauddin Zakariya University, Multan. Recommended tillage operations were adopted for the preparation of seedbeds for tomato seedlings. The pre-experimental soil characteristics are provided in Table 1. 
Table 1. Pre-transplantation soil characteristics.

\begin{tabular}{cccc}
\hline Characteristics & Units & Soil & References \\
\hline Textural class & - & Silt Loam & {$[18]$} \\
\hline $\mathrm{pH}_{s}$ & - & 8.20 & {$[19]$} \\
\hline $\mathrm{EC}_{e}$ & $\left(\mathrm{dS} \mathrm{m}^{-1}\right)$ & 2.10 & {$[20]$} \\
\hline Organic matter & $(\%)$ & 0.76 & {$[21]$} \\
\hline Total nitrogen & $(\%)$ & 0.038 & {$[22]$} \\
\hline Available phosphorus & $\left(\mathrm{mg} \mathrm{kg}^{-1}\right)$ & 8.6 & {$[23]$} \\
\hline Extractable potassium & $\left(\mathrm{mg} \mathrm{kg}^{-1}\right)$ & 172 & {$[24]$} \\
\hline HCl-extractable B & $\left(\mathrm{mg} \mathrm{kg}^{-1}\right)$ & 0.39 & {$[25]$} \\
\hline DTPA-extractable Zn & $\left(\mathrm{mg} \mathrm{kg}^{-1}\right)$ & 0.56 & \\
\hline DTPA-extractable Fe & $\left(\mathrm{mg} \mathrm{kg}^{-1}\right)$ & 6.40 & \\
\hline
\end{tabular}

\subsection{Tomato Seedling}

Tomato cv. Rio Grande seedlings (30 days old) were transplanted on beds $(120 \mathrm{~cm}$ apart at both sides) with a $45 \mathrm{~cm}$ plant-to-plant distance for the achievement of 16,500 plant population $\mathrm{ha}^{-1}[26]$.

\subsection{Macronutrients Application Rate and Time}

Nitrogen, P, and $\mathrm{K}$ were applied at 150, 100, and $100 \mathrm{~kg} \mathrm{ha}^{-1}$, respectively. Urea, diammonium phosphate, and sulphate of potash were added to the soil for macronutrient application. Nitrogen was applied in 3 splits, i.e., before transplantation, flowering initiation, and peak flowering stage. $\mathrm{P}$ and $\mathrm{K}$ were broadcasted before transplantation of tomato seedlings [27].

\subsection{Micronutrients (MC) Application Rate and Time}

Micronutrients were applied at the rate of $50\left(\mathrm{Zn}=2.50, \mathrm{~B}=0.75, \mathrm{Fe}=2.50 \mathrm{~kg} \mathrm{ha}^{-1}\right)$, $75\left(\mathrm{Zn}=3.75, \mathrm{~B}=1.125, \mathrm{Fe}=3.75 \mathrm{~kg} \mathrm{ha}^{-1}\right)$ and $100 \%\left(\mathrm{Zn}=5.0, \mathrm{~B}=1.5, \mathrm{Fe}=5.0 \mathrm{~kg} \mathrm{ha}^{-1}\right)$ [28]. After a month of transplanting tomato nursery seedlings, a mixture of micronutrients was applied in the soil. All micronutrient doses were applied in a single split.

\subsection{Potassium Humate (KH) Application Rate and Time}

Based on the previous screening experiment, two application rates of potassium humate (KH), i.e., 5, 10, and $15 \mathrm{~kg} \mathrm{ha}^{-1}$, were chosen. Potassium humate was applied in a single dose in the soil before the transplantation of tomato seedlings [29].

\subsection{Irrigation}

The first irrigation was applied just after transplanting the seedlings and continued regularly according to the requirement (65\% field capacity) of the crop during the growth period.

\subsection{Treatment Plan}

There were 16 treatments with three replications following randomized complete block design (RCBD). The treatments were $\mathrm{T} 1=\mathrm{control}(\mathrm{no} \mathrm{Zn}+\mathrm{Fe}+\mathrm{B}(\mathrm{MC})$ and no potassium humate $(\mathrm{KH})), \mathrm{T} 2=50 \% \mathrm{MC}, \mathrm{T} 3=75 \% \mathrm{MC}, \mathrm{T} 4=100 \% \mathrm{MC}, \mathrm{T} 5=5 \mathrm{~kg} \mathrm{ha}^{-1} \mathrm{KH}, \mathrm{T} 6=50 \% \mathrm{MC}$ $+5 \mathrm{~kg} \mathrm{ha}{ }^{-1} \mathrm{KH}, \mathrm{T} 7=75 \% \mathrm{MC}+5 \mathrm{~kg} \mathrm{ha}^{-1} \mathrm{KH}, \mathrm{T} 8=100 \% \mathrm{MC}+5 \mathrm{~kg} \mathrm{ha}^{-1} \mathrm{KH}$, $\mathrm{T} 9=10 \mathrm{~kg} \mathrm{ha}^{-1} \mathrm{KH}, \mathrm{T} 10=50 \% \mathrm{MC}+10 \mathrm{~kg} \mathrm{ha}^{-1}, \mathrm{~T} 11=75 \% \mathrm{MC}+10 \mathrm{~kg} \mathrm{ha}^{-1} \mathrm{KH}$, $\mathrm{T} 12=100 \% \mathrm{MC}+10 \mathrm{~kg} \mathrm{ha}^{-1} \mathrm{KH}, \mathrm{T} 13=15 \mathrm{~kg} \mathrm{ha}^{-1} \mathrm{KH}, \mathrm{T} 14=50 \% \mathrm{MC}+15 \mathrm{~kg} \mathrm{ha}^{-1}$, $\mathrm{T} 15=75 \% \mathrm{MC}+15 \mathrm{~kg} \mathrm{ha}^{-1} \mathrm{KH}$ and T $16=100 \% \mathrm{MC}+15 \mathrm{~kg} \mathrm{ha}^{-1} \mathrm{KH}$. 


\subsection{Harvesting and Analyses}

Plants were harvested at the time of maturity. Fruit yield was calculated by adding the fruit weight of all harvests per unit area. Freshly picked fruits were weighed on top balance for fruit fresh weight determination. Fruits were dried at $70{ }^{\circ} \mathrm{C}$ in an oven till constant weight. After that, the weight was taken as the dry weight of fruits. An average of 10 fruits was taken per treatment. The total weight of all the fruits harvested per plant was recorded during the whole season, added to above-ground fresh plant weight and fresh root weight, and total biomass was worked out. The ratio of fruit yield to biological yield known as harvest index (HI) was obtained by following the equation given below:

$$
\text { HI }(\%)=\text { Economic yield } \times 100 / \text { Total biomass }
$$

For $\mathrm{Zn}$ and Fe in fruit analyses, digestion was made using nitric acid and perchloric acid (2:1) [30]. Samples were digested by dry-ashing $\left(550{ }^{\circ} \mathrm{C}\right)$ in a muffle furnace for determining boron. After that, ash was dissolved in $10 \mathrm{~mL}$ of $0.36 \mathrm{~N} \mathrm{H}_{2} \mathrm{SO}_{4}$ and filtered using Whatman No. 42 filter paper. Finally, the Gaines and Mitchell (1979) method was used to assess B on spectrophotometer by taking absorbance at $410 \mathrm{~nm}$ wavelength [31].

\subsection{Statistical Analyses}

Two factorial analyses of variance were used to determine the significance of treatments at $p<0.05$. Interaction graphs were made on SPSS 20.0 to check the ordinal and subordinal interaction of $\mathrm{KH}$ and MC under the spring and autumn seasons.

\section{Results}

The main and interactive effects of MC and various potassium humate levels $(\mathrm{KH})$ were significant for tomato yield. Application of $100 \% \mathrm{MC}$ and $15 \mathrm{~kg} \mathrm{ha}^{-1} \mathrm{KH}$ differed significantly best over control for improving the tomato yield both in the autumn and spring seasons. A similar trend was noted at 75 and $50 \%$ MC when applied in combination with $15 \mathrm{~kg} \mathrm{ha}^{-1} \mathrm{KH}$ over control for improving the tomato yield both in autumn and spring. The increasing level of MC also improved the tomato yield both in autumn and spring (Table 2). The interaction of $\mathrm{KH}$ and $\mathrm{MC}$ was significant in both the autumn and spring seasons for the tomato's total fruit yield (Figure 1). A maximum increase of 7.4 and $7.17 \%$ in tomato yield was observed at $100 \% \mathrm{MC}$ and $15 \mathrm{~kg} \mathrm{ha}^{-1} \mathrm{KH}$ over control in autumn and spring.

Table 2. Total fruit yield (tons) per hectare of tomato affected by various K-humate and MC levels under the field conditions during spring.

\begin{tabular}{|c|c|c|c|c|c|}
\hline \multirow{2}{*}{ MC } & \multicolumn{4}{|c|}{ Potassium Humate Levels $\left(\mathrm{kg} \mathrm{ha}^{-1}\right)$} & \multirow{2}{*}{ Mean } \\
\hline & 0 & 5 & 10 & 15 & \\
\hline \multicolumn{6}{|c|}{ Autumn season } \\
\hline Control $(0 \%)$ & $24.15 \mathrm{k}$ & $24.40 \mathrm{~h}$ & $26.01 \mathrm{~g}$ & $26.92 \mathrm{e}$ & $25.62 d$ \\
\hline $50 \%$ & $24.43 \mathrm{j}$ & $25.96 \mathrm{~g}$ & $26.91 \mathrm{e}$ & $27.42 \mathrm{c}$ & $26.18 c$ \\
\hline $75 \%$ & $24.84 \mathrm{i}$ & $26.52 \mathrm{f}$ & $27.18 \mathrm{~d}$ & $28.55 b$ & $26.77 \mathrm{~b}$ \\
\hline $100 \%$ & $25.31 \mathrm{~h}$ & $26.94 \mathrm{e}$ & $28.46 b$ & $28.92 a$ & $27.41 \mathrm{a}$ \\
\hline Mean & $24.68 \mathrm{~d}$ & $26.20 c$ & $27.14 \mathrm{~b}$ & $27.95 a$ & \\
\hline \multicolumn{6}{|c|}{ Spring season } \\
\hline Control (0\%) & $25.75 \mathrm{k}$ & $27.04 \mathrm{~h}$ & $27.66 \mathrm{~g}$ & $28.59 \mathrm{e}$ & $27.26 \mathrm{~d}$ \\
\hline $50 \%$ & $26.05 j$ & $27.61 \mathrm{~g}$ & $28.58 \mathrm{e}$ & $29.10 \mathrm{c}$ & $27.83 c$ \\
\hline $75 \%$ & $26.47 \mathrm{i}$ & $28.18 \mathrm{f}$ & $28.86 \mathrm{~d}$ & $30.26 b$ & $28.44 b$ \\
\hline $100 \%$ & $26.95 \mathrm{~h}$ & $28.61 \mathrm{e}$ & $30.16 \mathrm{~b}$ & $30.64 a$ & $29.09 a$ \\
\hline Mean & $26.30 \mathrm{~d}$ & $27.86 \mathrm{c}$ & $28.81 \mathrm{~b}$ & $29.64 a$ & \\
\hline
\end{tabular}

Different letters on values show a significant statistical difference at $p \leq 0.05$. 

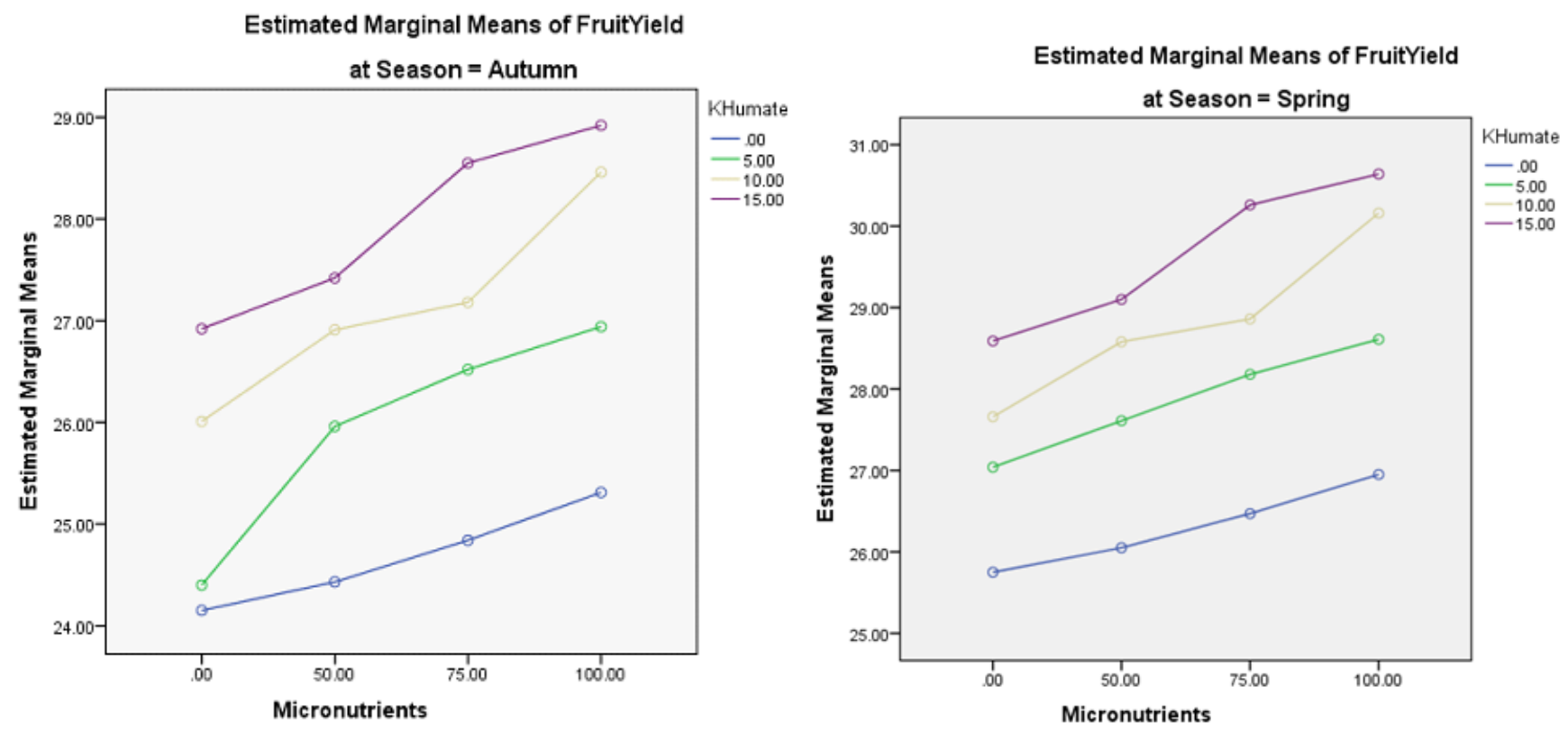

Figure 1. Interaction graphs for total fruit yield obtained under K-humate and micronutrients mixture applied in the autumn and spring seasons.

Both main and interactive effects of $\mathrm{MC}$ and $\mathrm{KH}$ were significant for the total biomass of tomatoes. Application of $100 \% \mathrm{MC}$ and $15 \mathrm{~kg} \mathrm{ha}^{-1} \mathrm{KH}$ remained significant over control for improving total biomass of tomatoes both in the autumn and spring seasons. A similar trend was noted at 75 and $50 \% \mathrm{MC}$ combined with $15 \mathrm{~kg} \mathrm{ha}^{-1} \mathrm{KH}$ over control to improve tomato's total biomass both in autumn and spring (Table 3). The increasing MC level also enhanced the total biomass of tomatoes both in the autumn and spring seasons. The interaction of $\mathrm{KH}$ and $\mathrm{MC}$ was significantly ordinal in the autumn and spring seasons for the tomatoes' total biomass (Figure 2). A maximum increase of 6.38 and $6.59 \%$ in total biomass of tomatoes was observed at $100 \% \mathrm{MC}+15 \mathrm{~kg} \mathrm{ha}^{-1} \mathrm{KH}$ over control in the autumn and spring seasons.

Table 3. Total biomass (tons) per hectare of tomatoes, affected by various K-humate and MC levels, under field conditions during autumn.

\begin{tabular}{|c|c|c|c|c|c|}
\hline \multirow{2}{*}{ MC } & \multicolumn{4}{|c|}{ Potassium Humate Levels (kg ha ${ }^{-1}$ ) } & \multirow{2}{*}{ Mean } \\
\hline & $\mathbf{0}$ & 5 & 10 & 15 & \\
\hline \multicolumn{6}{|c|}{ Autumn season } \\
\hline Control $(0 \%)$ & 54.381 & $57.05 \mathrm{~h}$ & $58.25 \mathrm{~g}$ & $60.00 \mathrm{e}$ & $57.42 d$ \\
\hline $50 \%$ & $54.84 \mathrm{k}$ & $58.08 \mathrm{~g}$ & $59.84 \mathrm{e}$ & $60.88 \mathrm{c}$ & $58.41 \mathrm{c}$ \\
\hline $75 \%$ & $55.62 \mathrm{j}$ & $59.16 \mathrm{f}$ & $60.36 \mathrm{~d}$ & $63.20 \mathrm{~b}$ & $59.58 b$ \\
\hline $100 \%$ & $56.54 \mathrm{i}$ & $59.86 \mathrm{e}$ & $62.95 b$ & $63.83 a$ & $60.79 a$ \\
\hline Mean & $55.34 d$ & $58.54 \mathrm{c}$ & $60.35 b$ & $61.98 \mathrm{a}$ & \\
\hline \multicolumn{6}{|c|}{ Spring season } \\
\hline Control (0\%) & 51.021 & $53.67 \mathrm{~h}$ & $54.85 \mathrm{~g}$ & $56.60 \mathrm{e}$ & $54.03 \mathrm{~d}$ \\
\hline $50 \%$ & $51.55 \mathrm{k}$ & $54.69 \mathrm{~g}$ & $56.43 \mathrm{e}^{\circ}$ & $57.44 \mathrm{c}$ & $55.02 \mathrm{c}$ \\
\hline $75 \%$ & $52.33 \mathrm{j}$ & $55.73 \mathrm{f}$ & $56.89 \mathrm{~d}$ & $59.69 \mathrm{~b}$ & $56.16 b$ \\
\hline $100 \%$ & $53.22 \mathrm{i}$ & $56.41 \mathrm{e}$ & $59.42 b$ & $60.33 a$ & $57.34 a$ \\
\hline Mean & $52.03 \mathrm{~d}$ & $55.12 \mathrm{c}$ & $56.89 \mathrm{~b}$ & $58.51 \mathrm{a}$ & \\
\hline
\end{tabular}

Different letters on values show a significant statistical difference at $p \leq 0.05$.

Both the main and interactive effects of $\mathrm{MC}$ and $\mathrm{KH}$ were significant for the harvesting index. Application of $100 \% \mathrm{MC}+15 \mathrm{~kg} \mathrm{ha}^{-1} \mathrm{KH}$ remained significant over control for improving the harvesting index of tomatoes both in the autumn and spring seasons. 
A similar trend was noted at 75 and $50 \% \mathrm{MC}+15 \mathrm{~kg} \mathrm{ha}^{-1} \mathrm{KH}$ over control for an increase in tomato harvesting index during autumn and spring (Table 4). The increasing MC level also improved the harvesting index of tomatoes both in the autumn and spring seasons. $\mathrm{KH}$ and $\mathrm{MC}$ interaction was significantly ordinal in both the autumn and spring seasons to harvest tomato (Figure 3). A maximum increase of 0.46 and $0.76 \%$ in harvesting tomato index was observed at $100 \% \mathrm{MC}+15 \mathrm{~kg} \mathrm{ha}^{-1} \mathrm{KH}$ over control in autumn and spring.
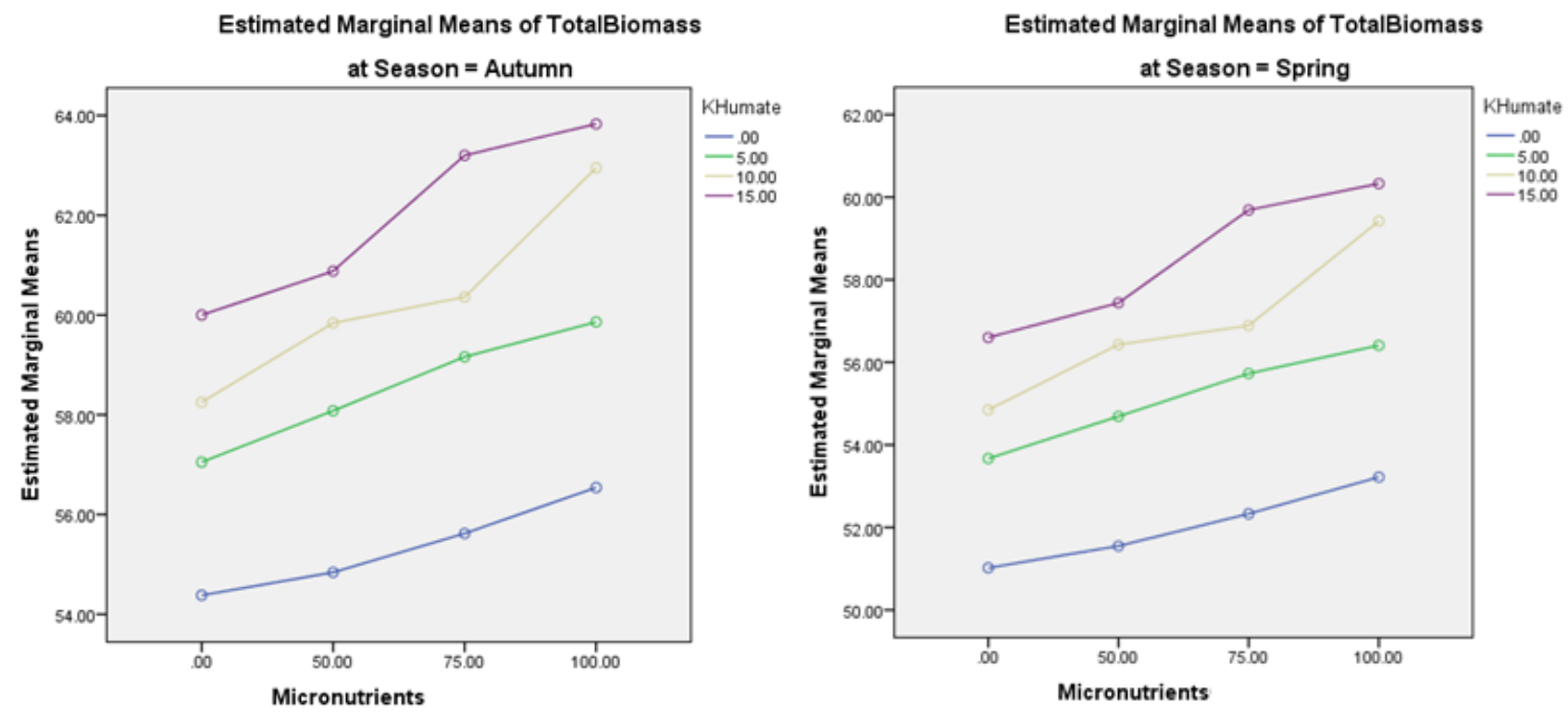

Figure 2. Interaction graphs for total fruit yield obtained under K-humate and micronutrients mixture applied in the autumn and spring seasons.

Table 4. Harvesting index of tomato as affected by various levels of K-humate and MC under the field conditions during autumn.

\begin{tabular}{|c|c|c|c|c|c|}
\hline \multirow{2}{*}{ MC } & \multicolumn{4}{|c|}{ Potassium Humate Levels (kg ha ${ }^{-1}$ ) } & \multirow{2}{*}{ Mean } \\
\hline & 0 & 5 & 10 & 15 & \\
\hline \multicolumn{6}{|c|}{ Autumn season } \\
\hline Control (0\%) & $47.33 \mathrm{k}$ & $47.35 \mathrm{k}$ & $47.42 \mathrm{i}$ & $47.55 \mathrm{~g}$ & $47.41 \mathrm{~d}$ \\
\hline $50 \%$ & $47.39 \mathrm{j}$ & $47.47 \mathrm{~h}$ & $56.10 \mathrm{e}$ & $47.75 \mathrm{~d}$ & $47.57 \mathrm{c}$ \\
\hline $75 \%$ & $47.47 \mathrm{~h}$ & $47.58 \mathrm{f}$ & $47.77 \mathrm{~d}$ & $47.83 \mathrm{c}$ & $47.66 \mathrm{~b}$ \\
\hline $100 \%$ & $47.57 \mathrm{fg}$ & $47.75 \mathrm{~d}$ & $47.89 \mathrm{~b}$ & $47.95 a$ & $47.79 \mathrm{a}$ \\
\hline Mean & $47.44 d$ & $47.54 \mathrm{c}$ & $47.70 \mathrm{~b}$ & $47.77 \mathrm{a}$ & \\
\hline \multicolumn{6}{|c|}{ Spring season } \\
\hline Control $(0 \%)$ & 47.351 & $47.40 \mathrm{k}$ & $47.48 \mathrm{j}$ & $47.65 \mathrm{fg}$ & $47.47 \mathrm{~d}$ \\
\hline $50 \%$ & $47.50 \mathrm{ij}$ & $47.53 \mathrm{i}$ & $57.74 \mathrm{e}$ & $47.81 \mathrm{~d}$ & $47.65 c$ \\
\hline $75 \%$ & $47.58 \mathrm{~h}$ & $47.63 \mathrm{~g}$ & $47.75 \mathrm{e}$ & $47.88 \mathrm{c}$ & $47.73 \mathrm{~b}$ \\
\hline $100 \%$ & $47.67 \mathrm{f}$ & $47.80 \mathrm{~d}$ & $47.91 \mathrm{~b}$ & 48.01a & $47.85 a$ \\
\hline Mean & $47.53 \mathrm{~d}$ & $47.59 c$ & $47.74 \mathrm{~b}$ & $47.84 a$ & \\
\hline
\end{tabular}

Different letters on values show a significant statistical difference at $p \leq 0.05$.

MC main effect was significant, but the main effect of $\mathrm{KH}$ and $\mathrm{MC} \times \mathrm{KH}$ remained non-significant for Zn concentration in tomatoes. Application of 100\% MC performed the significantly best control for increasing $\mathrm{Zn}$ concentration of tomato both in the autumn and spring seasons. It was noted that 50 and $75 \% \mathrm{MC}$ did not differ significantly for improving $\mathrm{Zn}$ concentration in the tomato fruit (Table 5). However, 50 and $75 \%$ MC significantly enhanced the $\mathrm{Zn}$ concentration in tomato fruit both in autumn and spring. The interaction of $\mathrm{KH}$ and $\mathrm{MC}$ was non-significantly ordinal in the autumn and spring seasons for the zinc concentration in tomatoes (Figure 4). A maximum increase of 41.3 and $41.8 \%$ in the $\mathrm{Zn}$ 
concentration of tomato was observed at $100 \%$ MC over control in the autumn and spring seasons, respectively.
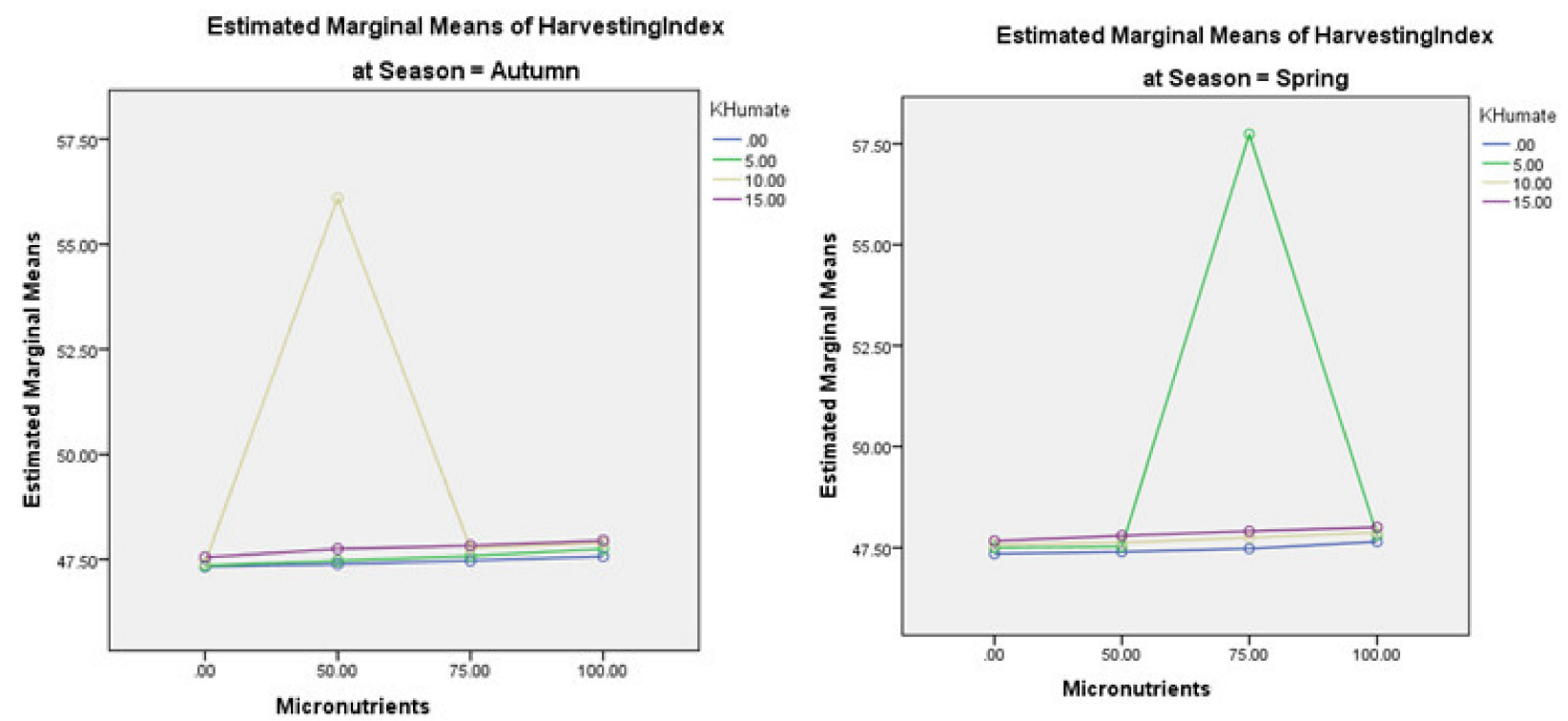

Figure 3. Interaction graphs for harvesting index obtained under K-humate and micronutrients mixture applied in the autumn and spring seasons.

Table 5. Zinc concentration $\left(\mathrm{mg} \mathrm{kg}^{-1}\right)$ in tomato fruit is affected by various K-humate and MC levels under field conditions during autumn.

\begin{tabular}{|c|c|c|c|c|c|}
\hline \multirow{2}{*}{ MC } & \multicolumn{4}{|c|}{ Potassium Humate Levels ( $\left.\mathrm{kg} \mathrm{ha}^{-1}\right)$} & \multirow{2}{*}{ Mean } \\
\hline & 0 & 5 & 10 & 15 & \\
\hline \multicolumn{6}{|c|}{ Autumn season } \\
\hline Control $(0 \%)$ & 28.8 & 30.8 & 31.8 & 33.5 & $31.2 b$ \\
\hline $50 \%$ & 33.5 & 38.8 & 40.8 & 41.8 & $38.7 \mathrm{a}$ \\
\hline $75 \%$ & 35.3 & 42.0 & 42.3 & 43.3 & $40.7 \mathrm{a}$ \\
\hline $100 \%$ & 35.3 & 44.8 & 46.8 & 49.8 & $44.1 \mathrm{a}$ \\
\hline Mean & 33.2 & 39.1 & 40.4 & 42.1 & \\
\hline \multicolumn{6}{|c|}{ Spring season } \\
\hline Control $(0 \%)$ & 29.3 & 31.3 & 32.3 & 34.3 & $31.8 \mathrm{~b}$ \\
\hline $50 \%$ & 34.3 & 39.5 & 41.8 & 42.8 & $39.6 a$ \\
\hline $75 \%$ & 36.0 & 42.8 & 43.0 & 44.0 & $41.4 \mathrm{a}$ \\
\hline $100 \%$ & 36.0 & 45.8 & 47.8 & 50.8 & $45.1 \mathrm{a}$ \\
\hline Mean & 33.9 & 39.8 & 41.2 & 42.9 & \\
\hline
\end{tabular}

No lettering is done for the non-significant main effect of $\mathrm{KH}$ and interaction of $\mathrm{KH}$ and micronutrients. Only a significant impact of micronutrients is provided with letters. Different letters on values show a significant statistical difference at $p \leq 0.05$.

MC main effect was significant, but the main effect of $\mathrm{KH}$ and $\mathrm{MC} \times \mathrm{KH}$ remained non-significant for B concentration in tomatoes. Application of $100 \%$ MC performed significantly best over control for increasing the B concentration of tomato fruit both in the autumn and spring seasons. It was noted that 50 and $75 \% \mathrm{MC}$ did not differ significantly for improving the $\mathrm{B}$ concentration in the tomato fruit during the autumn season. However, $100 \%$ MC significantly enhanced over $50 \%$ MC for the B concentration in tomato fruit during the spring season (Table 6). No significant change was noted among 50 and $75 \%$ $\mathrm{MC}$ during the spring season for B concentration in the tomato fruit. The interaction of $\mathrm{KH}$ and $\mathrm{MC}$ was non-significantly ordinal in both the autumn and spring seasons for $\mathrm{B}$ 
concentration in tomatoes (Figure 5). A maximum increase of 35.7 and $35.8 \%$ in the $\mathrm{B}$ concentration of tomatoes was observed at 100\% MC over control in autumn and spring.
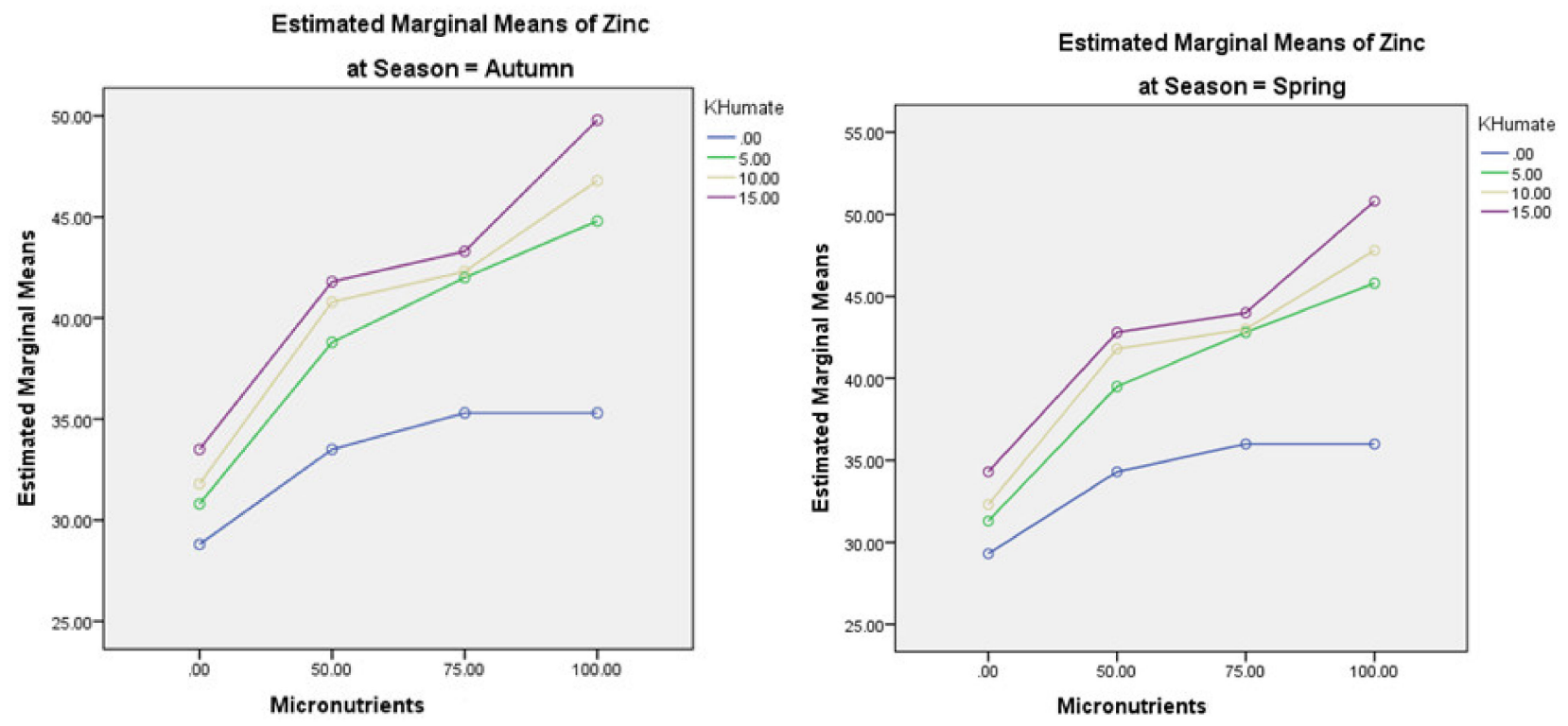

Figure 4. Interaction graphs for zinc concentration obtained in tomato fruit under K-humate and micronutrients mixture applied in the autumn and spring seasons.

Table 6. Effect of the boron concentration $\left(\mathrm{mg} \mathrm{kg}^{-1}\right)$ in the tomato fruit by various K-humate and MC levels under the field conditions during autumn.

\begin{tabular}{|c|c|c|c|c|c|}
\hline \multirow{2}{*}{ MC } & \multicolumn{4}{|c|}{ Potassium Humate Levels (kg ha $\left.{ }^{-1}\right)$} & \multirow{2}{*}{ Mean } \\
\hline & 0 & 5 & 10 & 15 & \\
\hline \multicolumn{6}{|c|}{ Autumn season } \\
\hline Control (0\%) & 26.0 & 26.8 & 28.0 & 28.8 & $27.4 \mathrm{~b}$ \\
\hline $50 \%$ & 28.8 & 31.0 & 32.8 & 33.5 & $31.5 \mathrm{ab}$ \\
\hline $75 \%$ & 29.5 & 34.3 & 35.8 & 36.5 & $34.0 \mathrm{a}$ \\
\hline $100 \%$ & 31.0 & 37.8 & 39.3 & 40.8 & $37.2 \mathrm{a}$ \\
\hline Mean & 28.8 & 32.4 & 33.9 & 34.9 & \\
\hline \multicolumn{6}{|c|}{ Spring season } \\
\hline Control $(0 \%)$ & 26.5 & 27.3 & 28.5 & 29.3 & $27.9 \mathrm{c}$ \\
\hline $50 \%$ & 29.3 & 31.5 & 33.5 & 34.3 & $32.1 b c$ \\
\hline $75 \%$ & 30.0 & 35.0 & 36.5 & 37.3 & 34.7ab \\
\hline $100 \%$ & 31.5 & 38.5 & 40.0 & 41.5 & $37.9 \mathrm{a}$ \\
\hline Mean & 29.3 & 33.1 & 34.6 & 35.6 & \\
\hline
\end{tabular}

No lettering is done for the non-significant effect of $\mathrm{KH}$ and interaction of $\mathrm{KH}$ and micronutrients. Only a significant impact of micronutrients is provided with letters. Different letters on values show a significant statistical difference at $p \leq 0.05$.

$\mathrm{MC}$ and $\mathrm{KH}$ main effects were significant, but $\mathrm{MC} \times \mathrm{KH}$ remained non-significant for Fe concentration in tomatoes. Application of $100 \%$ MC performed significantly higher compared to control for an increase in Fe concentration of tomatoes both in the autumn and spring seasons. Similarly, 10 and $15 \mathrm{~kg} \mathrm{ha}^{-1} \mathrm{KH}$ remained statistically alike to each other but significantly higher for Fe concentration in the tomato fruit. No significant change was noted where $5 \mathrm{~kg} \mathrm{ha}^{-1} \mathrm{KH}$ was applied over control for Fe concentration in the tomato fruit. It was noted that 50 and $75 \% \mathrm{MC}$ did not differ significantly for Fe concentration improvement in the tomato fruit during the autumn season. However, $100 \%$ MC significantly enhanced the Fe concentration over 50\% MC in the tomato fruit during spring (Table 7). No significant change was noted among 50 and 75\% MC during 
the spring season for $\mathrm{B}$ concentration in the tomato fruit. The interaction of $\mathrm{KH}$ and $\mathrm{MC}$ was non-significantly ordinal in both the autumn and spring seasons for $B$ concentration in tomatoes (Figure 6). A maximum increase of 35.7 and $35.8 \%$ in the B concentration of tomatoes was observed at $100 \% \mathrm{MC}$ over control in autumn and spring.
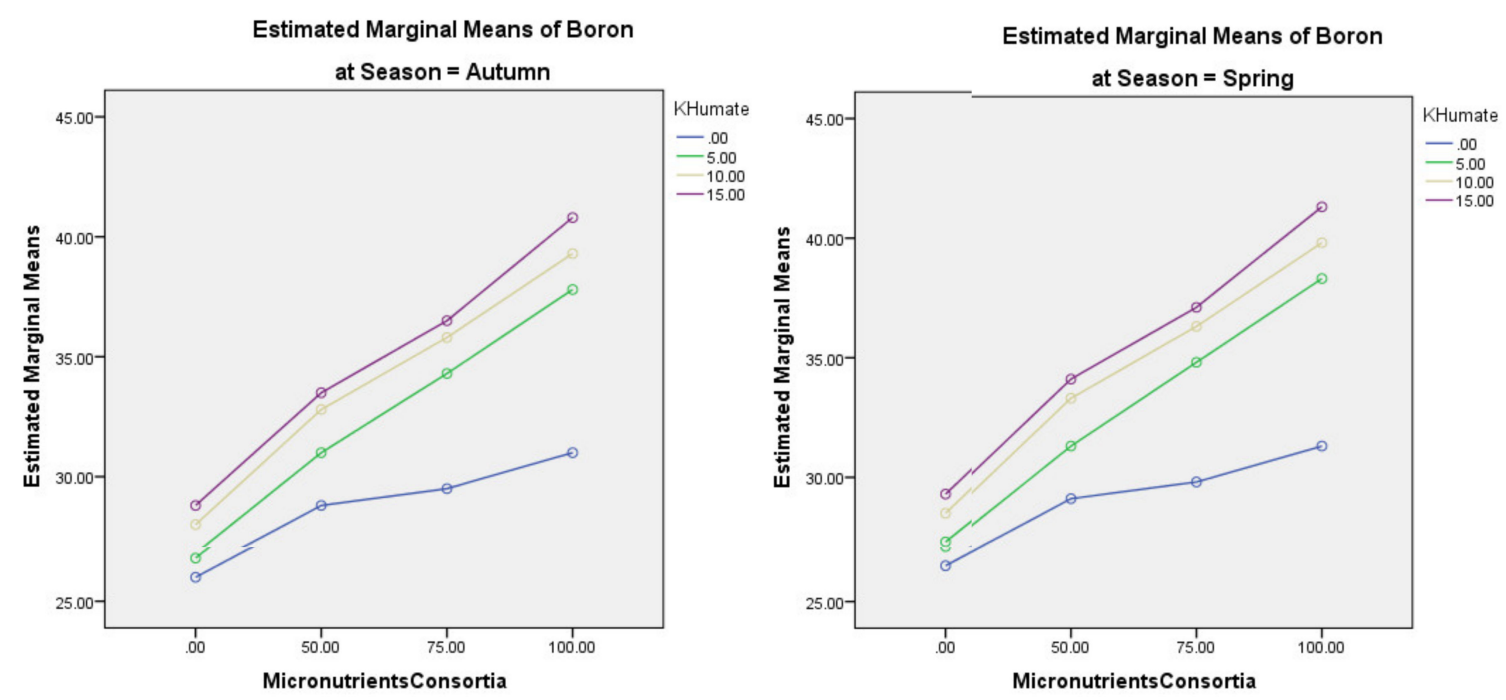

Figure 5. Interaction graphs for zinc concentration obtained in the tomato fruit under K-humate and micronutrients mixture applied in autumn and spring seasons.

Table 7. Iron concentration $\left(\mathrm{mg} \mathrm{kg}^{-1}\right)$ in tomato fruit as affected by various $\mathrm{K}$-humate and MC mixtures under field conditions during autumn.

\begin{tabular}{|c|c|c|c|c|c|}
\hline \multirow{2}{*}{ MC } & \multicolumn{4}{|c|}{ Potassium Humate Levels (kg ha ${ }^{-1}$ ) } & \multirow{2}{*}{ Mean } \\
\hline & $\mathbf{0}$ & 5 & 10 & 15 & \\
\hline \multicolumn{6}{|c|}{ Autumn season } \\
\hline Control $(0 \%)$ & 557.5 & 588.0 & 598.3 & 603.8 & $586.9 \mathrm{c}$ \\
\hline $50 \%$ & 614.0 & 617.8 & 619.0 & 621.8 & $618.1 b$ \\
\hline $75 \%$ & 614.5 & 622.8 & 624.3 & 624.3 & $621.4 \mathrm{ab}$ \\
\hline $100 \%$ & 615.8 & 624.3 & 627.5 & 715.3 & $645.7 \mathrm{a}$ \\
\hline Mean & $600.4 b$ & $613.2 b$ & 617.3ab & $641.3 \mathrm{a}$ & \\
\hline \multicolumn{6}{|c|}{ Spring season } \\
\hline Control $(0 \%)$ & 569.0 & 600.0 & 610.5 & 616.0 & $598.9 \mathrm{c}$ \\
\hline $50 \%$ & 626.5 & 630.3 & 631.5 & 634.3 & $630.6 \mathrm{~b}$ \\
\hline $75 \%$ & 626.8 & 635.3 & 637.0 & 637.0 & $634.0 \mathrm{ab}$ \\
\hline $100 \%$ & 628.3 & 637.0 & 640.3 & 729.8 & $658.8 \mathrm{a}$ \\
\hline Mean & $612.6 \mathrm{~b}$ & $625.6 \mathrm{~b}$ & 629.8ab & $654.3 a$ & \\
\hline
\end{tabular}

No lettering is done for non-significant interaction of KH and micronutrients. The only significant effect of micronutrients and $\mathrm{KH}$ is provided with letters. Different letters on values show a significant statistical difference at $p \leq 0.05$. 

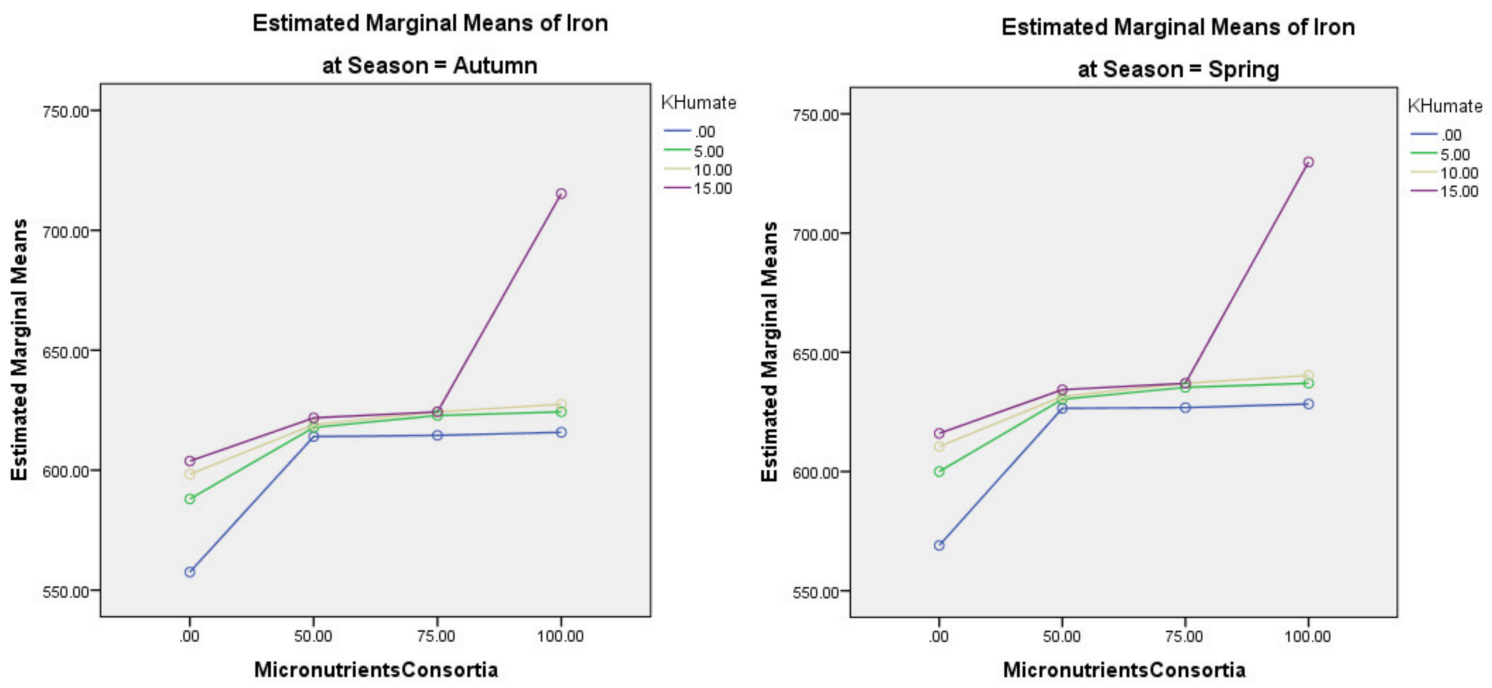

Figure 6. Interaction graphs for zinc concentration obtained in tomato fruit under K-humate and micronutrients mixture applied in the autumn and spring seasons.

\section{Discussion}

In this study, $\mathrm{KH}$ and $\mathrm{MC}$ significantly enhanced the yield of tomatoes. The maximum fruit yield was noted in plants where $15 \mathrm{~kg} \mathrm{KH} \mathrm{ha}^{-1}$ was applied under the MC variable level. Such improvement in the yield of tomato fruit was due to high/suitable availability of micronutrients to the plants. Our finding regarding enhancement in the yield is in agreement with Moccia et al. [32]. They observed that the application of organic amendment and $\mathrm{MC}$ increased the yield of cherry tomatoes.

$B$ application increases fruit size due to the better mobilization of food material from the production sites to storage organs and causes rapid fruit development. It was noted that foliar application was significantly effective for improving the mango fruit weight [33]. The higher yield was also associated with the greater number of flower formations due to boron absorption, and they also set a greater number of fruits [34,35]. Similar results were also noted in the current study, where yield per plant was enhanced due to boron and zinc application. The application of $\mathrm{Zn}$ also restricts the activity of dehydrogenase and proteinase enzymes. These enzymes are responsible for the fruit's early maturity, which deteriorates the quality attributes and minimizes fruit retention [36]. It was also noted that MC application performed significantly higher than control regarding the uptake of $\mathrm{Zn}, \mathrm{B}$, and Fe in tomato fruit.

A significant improvement in cell division and higher synthesis of proteins is also an additional benefit associated with improving the plants' growth when potassium humate is applied as an amendment in the soil $[37,38]$. The proliferation of microorganisms by application of potassium humate in the soil is also a fact. Plant growth-promoting microorganisms use potassium humate as a rich source of energy [39]. Improvement in the population of plant growth-promoting rhizobacteria also plays an influential role in improving crop productivity by secreting the enzymes and growth regulators [40-44]. In addition to the above, the presence of potassium humate in the soil stimulates the growth of the root. Such improvement in the root elongation played an imperative role in increasing the water and nutrients uptake in the vegetable crops [45].

On the other hand, $\mathrm{Zn}$ better uptake in crop plants facilitates the synthesis of carbohydrates [46]. The application of $\mathrm{Zn}$ also restricts the activity of dehydrogenase and proteinase enzymes. These enzymes are responsible for the fruit's early maturity, which deteriorates the quality attributes and minimizes fruit retention [36]. Fe concentration was significantly better where $\mathrm{KH}$ was applied at the rate of $15 \mathrm{~kg} \mathrm{ha}^{-1}$ over control. This improvement in $\mathrm{MC}$ concentration might be a result of the chelation of $\mathrm{MC}$ by KH. The potassium humate application increases the cation exchange capacity, which improves the soil's nutrients' 
holding capacity. The higher cation exchange capacity of the soil decreases the fixation of nutrients, enhancing the bioavailability of nutrients [47]. $\mathrm{MC}(\mathrm{Zn}+\mathrm{Fe}+\mathrm{B})$ significantly improved the crop yield due to B's beneficial role in pollination, $\mathrm{Zn}$ in growth-promoting substances, and Fe in the electron transport chain [48,49].

According to Jatav et al. [50], better development of fruit and seeds due to minimum oxidation of indole acetic acid and photosynthate translocation are positive effects of balanced B uptake in plants. Ribonucleic acid metabolism and stabilization of membrane by the balanced uptake of $B$ played an imperative role in the sugar assimilation, resulting in the optimum yield [51]. The higher yield was also associated with the greater number of flower formations due to boron absorption, and they also set a superior quality of fruits $[34,35]$.

Sivaiahet al. [48] applied MC as a treatment on tomatoes. They concluded that the increase in fresh-weight tomatoes was due to better uptake of nutrients. Improvement in nutrients uptake also facilitates metabolic activity and photosynthesis. Sánchez et al. [52] observed that the combination of Fe-EDDHA, humate/amino acids, enhanced Fe uptake via modification in plant metabolism. Since humate improves plant crops, it might be uptaken by the plants when applied as an amendment [53]. Davis et al. (2003) suggested that $\mathrm{K}$ and $\mathrm{B}$ have a synergistic effect [54]. The application of $\mathrm{B}$ also enhances $\mathrm{K}$ and $\mathrm{B}$ in the plants and plays an efficacious role in growth attributes. Humate substances stimulate plant physiological processes as a result of better macro and micronutrient uptake. Better plant nutrition enhances the synthesis of vitamins, hormones, and amino acids in plants [55].

\section{Conclusions}

In conclusion, 10 and $15 \mathrm{~kg} \mathrm{ha}^{-1} \mathrm{KH}$ with $100 \%$ MC constitute efficacious amendments for improving tomato yield and biomass during the spring and autumn seasons. Foliar application of $75 \% \mathrm{MC}$ is more economical for better uptake of Fe when applied with 10 and $15 \mathrm{~kg} \mathrm{ha}^{-1} \mathrm{KH}$ during the spring and autumn seasons. It is recommended to add $100 \%$ MC for balanced uptake of B and $\mathrm{Zn}$ in the soils that are deficient in $\mathrm{Zn}$ and B, regardless of the application rate of $\mathrm{KH}$. More investigations are also recommended under different climatic zones by applying 10 and $15 \mathrm{~kg} \mathrm{ha}^{-1} \mathrm{KH}$ with $100 \% \mathrm{MC}$ to declare it as the best amendment for tomatoes' yield improvement.

Author Contributions: Conceptualization, A.A.R., M.A.A. and J.I.M.; methodology, S.A.A. and S.D.; software, S.A.A., S.D. and T.D.M.; validation, A.A.R., M.A.A. and J.I.M.; formal analysis, A.A.R.; investigation, A.A.R.; resources, M.A.A. and J.I.M.; data curation, A.A.R.; writing-original draft preparation, A.A.R., S.A.A., S.D., R.D. and S.F.; writing-review and editing, A.A.R., S.A.A., S.D., R.D., S.F. and T.D.M.; visualization, M.A.A. and J.I.M.; supervision, M.A.A. and J.I.M. All authors have read and agreed to the published version of the manuscript.

Funding: This research received no external funding.

Acknowledgments: The paper is a part of the first author Ph.D. Dissertation.

Conflicts of Interest: The authors declare no conflict of interest.

\section{References}

1. Fageria, N.K.; Gheyi, H.R.; Moreira, A. Nutrient bioavailability in salt affected soils. J. Plant Nutr. 2011, 34, 945-962. [CrossRef]

2. Bose, U.; Tripathi, S. Effect of micronutrients on growth, yield and quality of tomato cv. Pusa Ruby in MP. Crop Res. 1996, 12, 61-64.

3. Yaseen, M.; Ahmed, W.; Shahbaz, M. Role of foliar feeding of micronutrients in yield maximization of cotton in Punjab. Turkish J. Agric. For. 2013, 37, 420-426. [CrossRef]

4. Tahir, F.A.; Ahamad, N.; Rasheed, M.K.; Danish, S. Effect of various application rate of zinc fertilizer with and without fruit waste biochar on the growth and Zn uptake in maize. Int. J. Biosci. 2018, 13, 159-166.

5. Bibi, F.; Saleem, I.; Ehsan, S.; Jamil, S.; Ullah, H.; Mubashir, M.; Kiran, S.; Ahmad, I.; Irshad, I.; Saleem, M.; et al. Effect of various application rates of phosphorus combined with different zinc rates and time of zinc application on phytic acid concentration and zinc bioavailability in wheat. Agric. Nat. Resour. 2020, 54, 265-272.

6. Osendarp, S.J.M.; West, C.E.; Black, R.E. The Need for Maternal Zinc Supplementation in Developing Countries: An Unresolved Issue. J. Nutr. 2003, 133, 817S-827S. [CrossRef] [PubMed] 
7. Shankar, A.H.; Prasad, A.S. Zinc and immune function: The biological basis of altered resistance to infection. Am. J. Clin. Nutr. 1998, 68, 447S-463S. [CrossRef]

8. Miwa, K.; Takano, J.; Fujiwara, T. Molecular mechanisms of boron transport in plants and its modification for plant growth improvement. Tanpakushitsu Kakusan Koso. 2008, 53, 1173-1179.

9. Takano, J.; Miwa, K.; Fujiwara, T. Boron transport mechanisms: Collaboration of channels and transporters. Trends Plant Sci. 2008, 13, 451-457. [CrossRef]

10. Dordas, C.; Apostolides, G.; Goundra, O. Boron application affects seed yield and seed quality of sugar beets. J. Agric. Sci. 2007, 145, 377. [CrossRef]

11. Bibi, F.; Ahmad, I.; Bakhsh, A.; Kiran, S.; Danish, S.; Ullah, H. Effect of Foliar Application of Boron with Calcium and Potassium on Quality and Yield of Mango cv. Summer Bahisht (SB) Chaunsa. Open Agric. 2019, 4, 98-106. [CrossRef]

12. Fortun, C.; Fortun, A.; Almendros, G. The effect of organic materials and their humified fractions on the formation and stabilization of soil aggregates. Sci. Total Environ. 1989, 81-82, 561-568. [CrossRef]

13. Danish, S.; Kiran, S.; Fahad, S.; Ahmad, N.; Ali, M.A.; Tahir, F.A.; Rasheed, M.K.; Shahzad, K.; Li, X.; Wang, D.; et al. Alleviation of chromium toxicity in maize by Fe fortification and chromium tolerant ACC deaminase producing plant growth promoting rhizobacteria. Ecotoxicol. Environ. Saf. 2019, 185, 109706. [CrossRef] [PubMed]

14. Chen, Y.; De Nobili, M.; Aviad, T. Stimulatory Effects of Humic Substances on Plant Growth. Soil Org. Matter Sustain. Agric. 2004, $28,103-129$.

15. Khristeva, L. Theory of Humic Fertilizers and Their Practical Use in the Ukraine. In 2nd International Peat Congress, Leningrad; Her Majesty's Stationery Office (HMSO): Edinburgh, UK, 1970; pp. 543-558.

16. Salam, M.; Siddique, M.; Rahim, M.; Rahman, M.; Saha, M. Quality of tomato (Lycopersicon esculentum Mill.) as influenced by boron and zinc under different levels of NPK fertilizers. Bangladesh J. Agric. Res. 1970, 35, 475-488. [CrossRef]

17. GOP. Vegetables and Condiments Statistics of Pakistan 2011-12. In Economic Wing; Government of Punjab, Ministry of National Food Security and Research: Islamabad, Pakistan, 2013; pp. 16-18.

18. Bouyouces, G.J. Hydrometer method improved for making particle size analysis of soil. Agron. J. 1962, 53, 464-465. [CrossRef]

19. Page, A.L.; Miller, R.H.; Keeny, D.R. Soil pH and lime requirement. In Methods of Soil Analysis; American Society of Agronomy: Madison, WI, USA, 1982; pp. 199-208.

20. Rhoades, J.D. Salinity: Electrical Conductivity and Total Dissolved Solids. In Methods of Soil Analysis, Part 3, Chemical Methods; Sparks, D.L., Page, A.L., Helmke, P.A., Loeppert, R.H., Soltanpour, P.N., Tabatabai, M.A., Johnston, C.T., Sumner, M.E., Eds.; Soil Science Society of America: Madison, WI, USA, 1996; Volume 5, pp. 417-435.

21. Nelson, D.W.; Sommers, L.E. Total Carbon, Organic Carbon, and Organic Matter. In Methods of Soil Analysis: Part 2 Chemical and Microbiological Properties; Page, A.L., Ed.; Merican Society of Agronomy: Madison, WI, USA; Crop Science Society of America: Madison, WI, USA; Soil Science Society of America: Madison, WI, USA, 1982; pp. 539-579.

22. Bremner, J.M.; Mulvaney, C.S. Nitrogen-total. In Methods of Soil Analysis, Part 2. Chemical and Microbiological Properties, 2nd ed.; Page, A.L., Miller, R.L., Keeney, D.R., Eds.; Merican Society of Agronomy; Crop Science Society of America; Soil Science Society of America: Madison, WI, USA, 1982; pp. 595-624.

23. Olsen, S.R.; Sommers, L.E. Phosphorus. In Method of Soil Analysis, Agron. No. 9, Part 2: Chemical and Microbiological Properties; Page, A.L., Ed.; American Society of Agronomy: Madison, WI, USA, 1982; pp. 403-430.

24. Pratt, P.F. Potassium. In Methods of Soil Analysis: Part 2 Chemical and Microbiological Properties, 9.2; Norman, A.G., Ed.; John Wiley \& Sons, Ltd: Hoboken, NJ, USA, 1965; pp. 1022-1030.

25. Katyal, J.C.; Sharma, B.D. DTPA-extractable and total $\mathrm{Zn}, \mathrm{Cu}, \mathrm{Mn}$, and Fe in Indian soils and their association with some soil properties. Geoderma 1991, 49, 165-179. [CrossRef]

26. Isah, A.S.; Amans, E.B.; Odion, E.C.; Yusuf, A.A. Growth Rate and Yield of Two Tomato Varieties (Lycopersicon esculentumMill) under Green Manure and NPK Fertilizer Rate Samaru Northern Guinea Savanna. Int. J. Agron. 2014, 2014, 1-8. [CrossRef] [PubMed]

27. GOP. Tomato Production Technology 2019-20; Directorate of Agriculture Information Government of The Punjab: Lahore, Pakistan, 2019. Available online: http:/ / dai.agripunjab.gov.pk/system/files/ChilliesPlan2019-20_0.pdf (accessed on 2 February 2021).

28. NFDC. Micronutrients in Agriculture: Pakistan Perspective; Publication No. 4/98; National Fertilizer Development Center: Islamabad, Pakistan, 1998. Available online: http:/ /www.nfdc.gov.pk/public.html (accessed on 2 February 2021).

29. Rahi, A.A.; Anjum, M.A.; Mirza, J.I. Integrated impact of micronutrients and potassium humate applications on growth, yield and fruit quality of tomato. Soil Environ. 2016, 35, 187-193.

30. Jones, J.J. Modern interpretation systems for soil and plant analyses in the United States of America. Aust. J. Exp. Agric. 1993, 33, 1039-1043. [CrossRef]

31. Gaines, T.P.; Mitchell, G.A. Boron determination in plant tissue by the azomethine H method. Commun. Soil Sci. Plant Anal. 1979, 10, 1099-1108. [CrossRef]

32. Moccia, R.; Bevan, D.; Reid, G. Composition of Fecal Waste from Commercial Trout Farms in Ontario: Macro and Micro Nutrient Analyses and Recommendations for Recycling; Aquaculture Centre University of Guelph: Guelph, ON, Canada, 2007; pp. 3-21.

33. Singh, S.; Parekh, N.S.; Patel, H.R.; Kore, P.N.; Vasara, R.P. Effect of Soil and Foliar Application of Multi Micronutrients on Fruit Yield and Physical Parameters of Fruit of Mango (Mangifera indica L.) var. Amrapali. Int. J. Curr. Microbiol. Appl. Sci. 2017, 6, 3495-3499. [CrossRef] 
34. Sarrwy, S.M.A.; Gadalla, E.G.; Mostafa, E.A.M. Effect of Calcium Nitrate and Boric Acid Sprays on Fruit Set, Yield and Fruit Quality of cv. Amhat Date Palm. World J. Agric. Sci. 2012, 8, 506-515.

35. Usenik, V.; Štampar, F. Effect of late season boron spray on boron accumulation and fruit set of 'Summit' and 'Hedelfinger' sweet cherry (Prunus avium L.). Acta Agric. Slov. 2008, 89, 51-58. [CrossRef]

36. Chandra, R.; Singh, K.K. Foliar application of zinc sulphate, magnesium sulphate and copper sulphate on the yield and quality of aonla ( Emblica officinallis Gaerth L.) cv. “ NA-7 " under Garhwal Himalaya. J. Med. Plants Stud. 2015, 3, 42-45.

37. El-Ghamry, A.M.; Abd El-Hai, K.M.; Ghoneem, K.M. Amino and humic acids promote growth, yield and disease resistance of faba bean cultivated in clayey soil. Aust. J. Basic Appl. Sci. 2009, 3, 731-739.

38. Patil, R. Effect of potassium humate and deproteinised Juice (DPJ) on seed germination and seedling growth of wheat and jowar. Ann. Biol. Res. 2010, 1, 148-151.

39. Pettit, R.E. Organic matter, humus, humate, humic acid, fulvic acid and humin: Their importance in soil fertility and plant health. CTI Res. 2014, 1, 1-17.

40. Danish, S.; Zafar-ul-Hye, M.; Hussain, M.; Shaaban, M.; Núñez-delgado, A. Rhizobacteria with ACC-Deaminase Activity Improve Nutrient Uptake, Chlorophyll Contents and Early Seedling Growth of Wheat under PEG-Induced Osmotic Stress. Int. J. Agric. Biol. 2019, 21, 1212-1220.

41. Danish, S.; Zafar-ul-Hye, M. Co-application of ACC-deaminase producing PGPR and timber-waste biochar improves pigments formation, growth and yield of wheat under drought stress. Sci. Rep. 2019, 9, 5999. [CrossRef] [PubMed]

42. Zafar-ul-Hye, M.; Zahra, M.B.; Danish, S.; Abbas, M.; Rehim, A.; Akbar, M.N.; Iftikhar, A.; Gul, M.; Nazir, I.; Abid, M.; et al. Multi-strain inoculation with pgpr producing acc deaminase is more effective than single-strain inoculation to improve wheat (Triticum aestivum) growth and yield. Phyton 2020, 89, 405-413. [CrossRef]

43. Danish, S.; Zafar-ul-Hye, M. Combined role of ACC deaminase producing bacteria and biochar on cereals productivity under drought. Phyton 2020, 89, 217-227. [CrossRef]

44. Ahmed, N.; Ahsen, S.; Ali, M.A.; Hussain, M.B.; Hussain, S.B.; Rasheed, M.K.; Butt, B.; Irshad, I.; Danish, S. Rhizobacteria and silicon synergy modulates the growth, nutrition and yield of mungbean under saline soil. Pak. J. Bot. 2020, 52, 9-15. [CrossRef]

45. Cimrin, K.M.; Yilmaz, I. Humic acid applications to lettuce do not improve yield but do improve phosphorus availability. Acta Agric. Scand. Sect. B Soil Plant Sci. 2005, 55, 58-63. [CrossRef]

46. Swietlik, D. Zinc Nutrition in Horticultural Crops. In Horticultural Reviews; John Wiley \& Sons, Inc.: New York City, NY, USA, 2010; pp. 109-178.

47. Liu, C.; Cooper, R.J.; Bowman, D.C. Humic acid application affects photosynthesis, root development, and nutrient content of creeping bentgrass. HortScience 1998, 33, 1023-1025. [CrossRef]

48. Sivaiah, S.; Srinivasa-Raju, R. Finite element solution of heat and mass transfer flow with Hall current, heat source, and viscous dissipation. Appl. Math. Mech. 2013, 34, 559-570. [CrossRef]

49. Shivanandam, V.; Pradeep, S.; Rajanna, K. Effect of zinc sulphate on growth and yield of mango varieties and hybrids. J. Soils Crop. 2007, 17, 225-229.

50. Jatav, H.S.; Sharma, L.D.; Sadhukhan, R.; Singh, S.K.; Singh, S.; Rajput, V.D.; Parihar, M.; Jatav, S.S.; Jinger, D.; Kumar, S.; et al. An Overview of Micronutrients: Prospects and Implication in Crop Production. In Plant Micronutrients: Deficiency and Toxicity Management; Aftab, T., Hakeem, K.R., Eds.; Springer Nature: Cham, Switzerland, 2020; pp. 4-5. ISBN 9783030498559.

51. Marschner, H. Marschner's Mineral Nutrition of Higher Plants, 3rd ed.; Marschner, P., Ed.; Academic Press: Cambridge, MA, USA, 2011.

52. Sánchez, A.S.; Juárez, M.; Sánchez-Andreu, J.; Jordá, J.; Bermúdez, D. Use of Humic Substances and Amino Acids to Enhance Iron Availability for Tomato Plants from Applications of the Chelate FeEDDHA. J. Plant Nutr. 2005, 28, 1877-1886. [CrossRef]

53. Nardi, S.; Pizzeghello, D.; Muscolo, A.; Vianello, A. Physiological effects of humic substances on higher plants. Soil Biol. Biochem. 2002, 34, 1527-1536. [CrossRef]

54. Davis, J.M.; Sanders, D.C.; Nelson, P.V.; Lengnick, L.; Sperry, W.J. Boron Improves Growth, Yield, Quality, and Nutrient Content of Tomato. J. Am. Soc. Hortic. Sci. 2003, 128, 441-446. [CrossRef]

55. Ameloot, N.; De Neve, S.; Jegajeevagan, K.; Yildiz, G.; Buchan, D.; Funkuin, Y.N.; Prins, W.; Bouckaert, L.; Sleutel, S. Shortterm $\mathrm{CO}_{2}$ and $\mathrm{N}_{2} \mathrm{O}$ emissions and microbial properties of biochar amended sandy loam soils. Soil Biol. Biochem. 2013, 57, 401-410. [CrossRef] 